\title{
GAMBARAN TINGKAT PENGETAHUAN PASIEN TENTANG \\ KONTRASEPSI ORAL DI PUSKESMAS JONGAYA \\ KECAMATAN TAMALATE
}

\author{
Murniati $^{1}$ \\ Jurusan Farmasi Politeknik Sandi Karsa ${ }^{1}$
}

\begin{abstract}
ABSTRAK
Tujuan dari penelitian ini adalah untuk mengetahui Gambaran Tingkat Pengetahuan Pasien Tentang Kontrasepsi Oral Di Puskesmas Jongaya Kecamatan Tamalate. Jenis penelitian ini adalah penelitian deskriptif dengan teknik pengambilan sampel menggunakan Purposive Sampling, sampel yang diperoleh sebanyak 45 responden. Hasil penelitian menunjukan tingkat pengetahuan Penggunaan pil KB $(82,5 \%)$ dan tingkat pengetahuan Efek samping pil KB (85,33\%). sehingga hasil penelitian dapat disimpulkan bahwa tingkat pengetahuan kontrasepsi oral di Puskesmas Jongaya termasuk dalam kategori Baik sebanyak (84,07\%).
\end{abstract}

Kata Kunci: Tingkat Pengetahuan, Kontrasepsi Oral, Puskesmas

Coresponden Author:

Murniati

murniatinaurah@gmail.com 


\section{PENDAHULUAN}

\section{A. Latar Belakang}

Indonesia sebagai salah satu Negara berkembang juga tidak luput dari masalah kependudukan. Secara garis besar, masalahmasalah pokok di bidang kependudukan yang di hadapi di Indonesia antara lain penyebaran penduduk yang tidak merata, struktur umur muda, kualitas penduduk yang masih harusdi tingkatkan dan jumlah penduduk besar dengan laju pertumbuhan penduduk yang relative tinggi. Untuk mengurangi masalah tersebut, pemerintah menganjurkan untuk menggunakan KB. (Sulistyawati, 2011).

Ada beberapa metode keluarga berencana yang di anjurkan oleh pemerintah diantaranya, KB metode sederhana (kondom, pantang berkala, dengan system kalender, pantang berkala dengan system suhu basal, senggama terputus, dan spermisida), KB metode efektif (kontrasepsi hormonal, kontrasepsi hormonal pil, kontrasepsi hormonal suntikan, kontrasepsi hormonal susuk/norplant atau implant). Kontrasepi mekanis (alat kontrasepsi dalam rahim (AKDR), metode KB darurat (metode hormonaldan metode insersi AKDR), Kontrasepsi mantap (kontap) untuk pria dan wanita dengan tubektomi. (Ayu, 2010).

Ragam metode yang di tawarkan sesuatu program di dasarkan pada banyak factor, misalnya kebijakan program nasional, ketersediaan fasilitas dan petugas kesehatan, biaya, kecendrungan penyedia layanan, analisis pilihan, pemakai, dalam program, dan ketersediaan kontrasepsi yang di berikan secara Cuma-Cuma. Pola pemakai metode yang muncul saat individu memilih suatu metode tertentu diantara metode-metode yang di tawarkan bergantung pada ragam metode yang di sediakan, pada factor program yang lain (misalnya beberapa luas informasi yang di sediakan mengenai berbagai metode dan kualitas konseling), serta pada kebutuhan dan preferensi klien. Seluruh prevalensi pemakaian kontrasepsi yang terjadi akibat suatu rangkaian tertentu pilihan kontrasepsi sangat menentukan apa suatu program berhasil atau gagal atau tujuan demogratifnya, selain itu, ragam metode yang di tawarkan kepada klien dapat menimbulkan dampak besar bagi kepuasan klien. (Wulansari P, dkk, 2006).

Pil KB oral merupakan tablet pil yang di anggap sebagai suatu metode kontrasepsi yang dapat di percaya. Semua pil mengandung estrogen dan progesterone, kandungan estrogen di dalam biasanya menghambat ovulasi dan menekan perkembangan sel telur yang di buahi.
Mungkin juga dapat menghambat impantasi sedangan progesterone dalam pilakan menentalkan lender servik untuk mencegah masuknya sperma. Hormon ini juga mencegah kontrasepsi dengan cara memperlambat transpotrasi telur dan menghambat ovulsai. (Nurannisa S, 2013).

Jika kontrasepsi oral di konsumsi secara benar dan konsisten, di serap secara normal, dan metabolismenya tidak meningkat oleh interaksi dengan obat lain, maka kehandalan kontrasepsi oral mendekati $100 \%$.

Pil dapat digunakan setiap saat selagi haid untuk meyakinkan perempuan itu tidak hamil. Pil diminum pada hari pertama sampai hari ke-7 siklus haid. Boleh menggunakan pada hari ke-8, tetapi perlu menggunakan metode kontrasepsi yang lain (kondom) mulai hari ke-8 sampai hari ke-14 atau tidak melakukan hubungan seksual sampai telah menghabiskan paket pil tersebut. Pil sebaiknya di konsumsi setiap hari, lebih baik pada saat yang sama setiap hari. Pil yang pertama dimulai pada hari pertama sampai hari ke-7 siklus haid.

Berdasarkan hasil penelitian yang di lakukan oleh Danilla F.Y (2014) menunjukan bahwa pengetahuan tentang kontrasepsi oral pada akseptor KB pil masih dalam kategori cukup.

Pengetahuan akseptor KB pil yang mayoritas baik dapat mempengaruhi keberhasilan dari program KB untuk mencegah terjadinya perkembangan penduduk yang terlalu pesat.

Data yang diperoleh dari Puskesmas Jongaya tahun 2018 dengan jumlah akseptor aktif sebanyak 1099 akseptor. Akseptor KB suntikan $(61,4 \%)$, pil $(36,8 \%)$, implant $(7,27 \%)$, dimana yang menggnakan IUD sebanyak $(9,0 \%)$, implant sebanyak $(6,87 \%)$, dan pil sebanyak (38,9\%). Dari tahun 2017 masih di dapatkan 23 akseptor KB pil yang gagal dan pada tahun 2018 didapatkan 12 akseptor gagal dalam menggunakan kontrasepsi berikut dan hanya mengetahui sedikit tentang kontrasepsi pil diantaranya terdapat akseptor mengatakan selalu patuh untuk minum pil dan ada yang mengatakan kadang-kadang saat minum pil.

Dari data diatas terlihat bahwa penggunaan pil menempati urutan ke dua dari kontrasepsi suntik dan masih terdapat akseptor yang gagal dalam menggunakan kontrasepsi pil oral dalam kurung waktu tersebut.

Berdasarkan uraian diatas, maka peneliti tertarik untuk mencari tahu mengenai Gambaran Tingkat Pengetahuan Pasien Tentang Kontrasepsi Oral Di Puskesmas Jongaya Kecamatan Tamalate. 


\section{B. Rumusan Masalah}

Berdasarkan uraian latar belakang di atas, maka dapat di rumuskan masalah yaitu "Bagaimanakah Gambaran Tingkat Pengetahuan Pasien Tentang Kontrasepsi Oral Di Puskesmas Jongaya Kecamatan Tamalate?

\section{Tujuan Penelitian}

Untuk mengetahui Gambaran Tingkat Pengetahuan Pasien Tentang Kontrasepsi Oral Di Puskesmas Jongaya Kecamatan Tamalate.

\section{Manfaat Penelitian}

Sebagai salah satu sumber informasi bagi penentu kebijakan dan pelaksanaan program baik di lingkungan kesehatan khususnya di Puskesmas Jongaya Kecamatan Tamalate dalam penyusunan program perencanaan yang berkaitan dengan upaya untuk meningkatkan pengetahuan KB khususnya akseptor pil oral.

\section{METODE PENELITIAN}

\section{A. Jenis Penelitian}

Jenis penelitian ini adalah penelitian deskriptif, untuk Mengetahui Tingkat Pengetahuan tentang pil KB oral pada Ibu-Ibu di Puskesmas Jongaya Kecamatan Tamalate.

\section{B. Waktu Dan Tempat Penelitian}

Penelitian ini dilakukan di Puskesmas Jongaya Kecamatan Tamalate. Selama bulan Oktober 2020.

\section{Populasi dan Sampel}

a. Populasi

Populasi dalam penelitian ini adalah pasien yang menggunakan pil KB di Puskesmas Jongaya Kecamatan Tamalate.

b. Sampel

Metode pengambilan sampel di puskesmas Jongaya Kecamatan Tamalate adalah dengan cara Purposive Sampling yang memenuhi kriteria sebagai berikut:

1. Minimal selama 2 tahun yang menggunakan Pil KB

2. Usia 20-35 tahun.

3. Sehat jasmani dan rohani

4. Bersedia mengisi kuesioner

\section{Teknik Pengumpulan Data dan Pengolahan} Data

a. Pengumpulan Data

Data yang di ambil adalah data primer hasil wawancara langsung menggunakan kuisioner.

b. Pengolahan Data
Data yang di peroleh atau di kumpulkan melalui kuesioner maka dapat di olah secara manual melalui editing, coding, entry, dan tabulation.

Data yang diperoleh dengan teknik pengolahan data berdasarkan skala Guttman yaitu dimana:

Skor jawaban benar: 2

Skor jawaban salah: 1

Data hasil kuesioner kemudian dipersentase dimana:

1. Baik: Responden menjawab $84 \%$ sampai dengan $100 \%$ benar.

2. Cukup Baik: Responden Menjawab 67\% sampai dengan $73 \%$ benar.

3. Kurang Baik: Responden menjawab kurang dari $50 \%$ jawaban benar.

Data yang diperoleh diolah dengan menggunakan skala likert, sebagai berikut:

Persentase $=$

$\frac{j u m l a h \text { hasil }}{\text { skor nilai terting gi } \sum \text { item } \sum \text { responden }} X 100 \%$

(Sumber: Riduwan, 2013)

\section{E. Defenisi Operasional}

Table I. Definisi Operasional

\begin{tabular}{lllll}
\hline No & $\begin{array}{c}\text { Defenisi } \\
\text { operasinal }\end{array}$ & Cara ukur & $\begin{array}{c}\text { Instrumen } \\
\text { penelitian }\end{array}$ & Hasil ukur \\
\hline 1 & Pengetahu & Pernyataan & Kuesioner & $\begin{array}{l}\text { Dikatakan } \\
\text { berpengetahuan }\end{array}$ \\
& an tentang & yang ada & & Baik jika \\
kontrasepsi & dikuesioner & & responden \\
& menjawab 84\% \\
& Ibu - ibu di & perjumlah 9 & & sampai dengan \\
& Puskesmas & dengan & $100 \%$ benar, \\
& Jongaya & pengukuran & dikatakan Cukup \\
Kecamatan & skala likert & Baik jika \\
Tamalate & yang & responden \\
& nilainya & menjawab 67\% \\
& yaitu: untuk & sampai dengan \\
& jawaban & & 73\% benar dan \\
& Benar diberi & dikatakan \\
& nilai(2), dan & Kurang Baik jika \\
& jawaban & responden \\
& salah diberi & menjawab \\
& nilai (1). & kurang dari 50\% \\
& & jawaban benar. \\
\hline
\end{tabular}

\section{HASIL DAN PEMBAHASAN}

\section{A. Hasil Penelitian}

Hasil penelitian mengenai Tingkat Pengetahuan tentang Kontrasepsi Oral Pada IbuIbu Di Puskesmas Jongaya Kecamatan Tamalate Kota Makassar di laksanakan bulan Juni, maka di peroleh sampel sebanyak 45 responden. 
Penelitian ini adalah jenis penelitian deskriptif dengan menggunakan purposive sampling yang bermaksud memaparkan karakteristik masalah yang diteliti kemudian menarik kesimpulan berdasarkan data yang diperoleh yang dijelaskan dalam bentuk tabel distribusi frekuensi.

Adapun hasil yang diperoleh penelitian ini adalah sebagai berikut:

1. Karakteristik Responden

Karakteristik responden adalah data umum responden yang terdiri atas umur, pendidikan terakhir, dan pekerjaan yang diperoleh saat penelitian dilaksanakan di Puskesmas Jongaya Kecamatan Tamalate. Hasil karaktristik responden tersebut akan diuraikan pada table berikut: 1

Tabel I. Distrbusi Frekuensi data Responden di Puskesmas Jongaya Kecamatan Tamalate

\begin{tabular}{cccc}
\hline No & Kategori & $\begin{array}{c}\text { Frekuensi } \\
\text { (Responden) }\end{array}$ & $\begin{array}{c}\text { Persentase } \\
(\%)\end{array}$ \\
\hline 1 & Usia & & \\
& $21-25$ & 26 & 58,0 \\
2 & $26-35$ & 19 & 42,0 \\
& Pendidikan & & \\
& SD & 14 & 31,1 \\
& SMP & 12 & 26,7 \\
& SMA & 6 & 13,3 \\
& D3 & 8 & 18,0 \\
& S1 & 5 & 11,0 \\
3 & Pekerjaan & & \\
& IRT & 32 & 71,1 \\
& PETANI & 3 & 6,7 \\
& PNS & 10 & 22,2 \\
\hline & Jumlah & $\mathbf{4 5}$ & $\mathbf{1 0 0}$ \\
\hline
\end{tabular}

Berdasarkan table I menunjukan bahwa dari 45 responden, dapat diketahui distribusi responden menurut umur pada usia 26-35 tahun yaitu sebanyak 19 responden $(42,0 \%)$, dan kelompok umur 21-25 sebanyak 26 (58,0\%).

Karakteristik responden menurut pendidikan menunjukan bahwa dari 45 responden, dapat diketahui bahwa distribusi responden menurut pendidikan terbanyak pada tingkat pendidikan SMP/sederajat sebanyak 12 responden $(26,7 \%)$ kemudian diikuti tamatan SD/sederajat sebanyak 14 responden $(21,1 \%)$ dan tamatan D3 sebanyak 8 responden $(18,0 \%)$, S1 sebanyak 5 responden $(11,1 \%)$, dan SMA sebanyak 6 responden $(13,3 \%)$.

Karakteristik responden menurut pekerjaan menunjukan bahwa dari 45 responden, dapat diketahui bahwa distribusi responden menurut pekerjaan terbanyak pada kelompok pekerjaan sebagai ibu rumah tangga (IRT) yaitu sebanyak 32 responden $(71,1 \%)$ dan diikuti kelompok pekerjaan PNS 10 responen $(22,2 \%)$, dan kelompok pekerja sebagai PETANI sebanyak 3 responden $(6,7 \%)$.

Tabel II. Distribusi frekuensi tingkat pengetahuan pil KB Puskemas Jongaya Kecamatan Tamalate (Pengetahuan tentang Penggunaan pil $\mathrm{KB})$.

\begin{tabular}{|c|c|c|c|c|}
\hline \multirow{2}{*}{ No } & \multirow{2}{*}{ Pernyataan } & \multicolumn{2}{|c|}{ Jawaban } & \multirow{2}{*}{$\begin{array}{c}\text { Persentase } \\
(\%)\end{array}$} \\
\hline & & Benar & Salah & \\
\hline 1 & $\begin{array}{l}\text { Penggunaan } \\
\text { pil KB secara } \\
\text { teratur dapat } \\
\text { melancarkan } \\
\text { siklus haid }\end{array}$ & 30 & 15 & 66,6 \\
\hline 2 & $\begin{array}{l}\text { Pil KB } \\
\text { sebaiknya } \\
\text { diminum } \\
\text { setiap hari dan } \\
\text { apabila lupa } \\
\text { segera } \\
\text { diminum pil } \\
\text { setelah ingat }\end{array}$ & 28 & 17 & 62,2 \\
\hline 3 & $\begin{array}{l}\text { Ibu tidak } \\
\text { boleh minum } \\
2 \text { pil KB } \\
\text { sekaligus pada } \\
\text { malam hari } \\
\text { ketika lupa } \\
\text { minum pil } \\
\text { pada jadwal } \\
\text { malam hari }\end{array}$ & 30 & 15 & 66.6 \\
\hline 4 & $\begin{array}{l}\text { Waktu } \\
\text { menggunakan } \\
\text { pil KB } \\
\text { pertama kali } \\
\text { adalah saat } \\
\text { haid hari } \\
\text { pertama } \\
\text { berlangsung } \\
\end{array}$ & 29 & 16 & 64,4 \\
\hline & Jumlah & 117 & 63 & 64,95 \\
\hline
\end{tabular}

$$
\begin{aligned}
& \text { Persentase } \\
& \text { skor } \\
& \frac{(\text { jumlah benar x 2)+(jumlah salah x 1) }}{\text { total skor ideal }} \times 100 \% \\
& =\frac{(117 \times 2)+(63 \times 1)}{45 \times 4 \times 2} \times 100 \% \\
& =\frac{234+63}{360} \times 100 \% \\
& =\frac{297}{360} \times 100 \% \\
& =82,5
\end{aligned}
$$

\begin{tabular}{|c|c|c|c|c|}
\hline \multirow{2}{*}{ No } & \multirow{2}{*}{ Pernyataan } & \multicolumn{2}{|c|}{ Jawaban } & \multirow{2}{*}{$\begin{array}{c}\text { Persentase } \\
(\%)\end{array}$} \\
\hline & & Benar & Salah & \\
\hline 1 & $\begin{array}{l}\text { Efek samping } \\
\text { dari pil KB salah } \\
\text { satunya adalah } \\
\text { penurunan } \\
\text { tingkat keinginan } \\
\text { berhubungan } \\
\text { seksual }\end{array}$ & 36 & 9 & 80 \\
\hline 2 & $\begin{array}{l}\text { Wanita yang } \\
\text { sudah mengalami }\end{array}$ & 35 & 10 & 77,8 \\
\hline
\end{tabular}

Table III. Pengetahuan tentang efek samping Pil $\mathrm{KB}$ 


\begin{tabular}{|c|c|c|c|c|}
\hline & $\begin{array}{l}\text { menopause masih } \\
\text { dapat } \\
\text { menggunakan pil } \\
\text { KB }\end{array}$ & & & \\
\hline 3 & $\begin{array}{l}\text { Kontrasepsi pil } \\
\text { KB efek samping } \\
\text { pengguna bisa } \\
\text { menaikan berat } \\
\text { badan }\end{array}$ & 27 & 18 & 60 \\
\hline 4 & $\begin{array}{l}\text { Ibu yang sedang } \\
\text { menyusui dapat } \\
\text { menggunakan pil } \\
\text { KB yang berisi } \\
\text { estrogen dan } \\
\text { progesterone }\end{array}$ & 29 & 16 & 64,4 \\
\hline 5 & $\begin{array}{l}\text { Beberapa obat } \\
\text { dapat } \\
\text { menyebabkan } \\
\text { ketidak aturan } \\
\text { mensturasi, } \\
\text { ovulasi dan } \\
\text { kadang } \\
\text { kegagalan obat } \\
\text { KB oral }\end{array}$ & 32 & 13 & 71,1 \\
\hline & Jumlah & 159 & 66 & 70,78 \\
\hline
\end{tabular}

Persentase skor $=$

$$
\begin{aligned}
& =\frac{(\text { Jumlah Benar } \times 2)+(\text { Jumlah Kalah } \times 1)}{\text { Total Skor Ideal }} \times 100 \% \\
& =\frac{(159 \times 2)+(66 \times 1)}{45 \times 5 \times 2} \times 100 \% \\
& =\frac{318+66}{450} \times 100 \% \\
& =\frac{384}{450} \times 100 \% \\
& =85,33 \%
\end{aligned}
$$

Total skor

Presentase skor

$$
\begin{aligned}
& =\frac{(\text { jumlah benar } \times 2+\text { jumlah salah } \times 1)}{\text { total skor ieal }} \times 100 \\
& =\frac{(276 \times 2)+(129 \times 1)}{45 \times 9 \times 2} \times 100 \% \\
& =\frac{552+129}{810} \times 100 \% \\
& =\frac{681}{810} \times 100 \% \\
& =84,07 \%
\end{aligned}
$$

$$
\begin{aligned}
& =\frac{681}{810} \times 100 \% \\
& =84,07 \%
\end{aligned}
$$

\section{B. Pembahasan}

1. Distribusi tingkat pengetahuan tentang cara penggunaan pil oral

Tabel III dan IV menunjukan bahwa dari 45 responden, dapat diketahui bahwa distribusi responden yang memiliki kategori Tahu sebanyak (82,5\%), Cukup tahu $(64,4 \%)$ dan yang memiliki kategori kurang tahu sebanyak $(62,2 \%)$. Berdasarkan tingkat pengetahuan tentang cara penggunaan pil.

Data tersebut tampak bahwa jumlah responden yang tingkat pengetahuan tentang cara penggunaan pil oral memiliki pengetahuan yang baik dan cukup hal ini mungkin dipengaruh ioleh pengetahuan KB pil oral yang mayoritas Tahu memahami pentingnya mengkonsumsi pil oral setiap hari dan sesuai aturan penggunaan sehingga tidak mengalami kegagalan. Namun masih ada sebagian responden yang menjawab salah tentang cara penggunaan pil oral, ini berarti kurangnya minat ibu membaca, kurangnya informasi dari petugas kesehatan, teman, maupun tetangga.

Sebagaimana yang kita ketahui bahwa cara penggunaan pil oral yaitu dengan cara sebaiknya diminum setiap hari pada saat yang sama, dan bila minum pil segera minum pil setelah diingat pada hari yang sama. Karena pil oral merupakan alat kontrasepsi yang dapat memiliki efektifitas yang tinggi lebih dari $99 \%$. Apabila lupa minum 1-2 pil maka dapat terjadi peningkatan hormone alamiah yang dapat mengakibatkan terjadinya pelepasan ovum.

2. Kategori pengetahuan tentang efek samping pada KB pil oral di Puskesmas

Jongaya Kecamatan Tamalate yang mempengaruhi kategori Tahu sebanya $(85,33 \%)$ cukup Tahu $(0,8 \%)$ dan kurang Tahu (71,1\%). Berdasarkan tingkat pengetahuan efek samping pil mudah menyesuaikan dengan hal baru tersebut. Pendidikan yang lebih tinggi berarti mempunyai wawasan dan pengalaman yang lebih luas, lebih muda memahami informasi yang diterima. Umur dapat dikaitkan dengan pengalaman. Semakin tua umur maka semakin banyak pengalaman yang didapat dan semakin banyak pula informasi yang diperoleh. (Nototmodjo, 2007).

Dari penelitian yang telah dilakukan menunjukan bahwa ibu masih memiliki tingkat pengetahuan yang kurang tentang pil. Pada 
umumnya akseptor perlu mengetahui tentang kontrasepsi pil oral karena jika pengetahuan pil masih kurang, itu dapat mempengaruhi proses program pelayanan $\mathrm{KB}$ dan pertumbuhan penduduk semakin tidak bisa dikendalikan. Peneliti juga beranggapan bahwa rendahnya pengetahuan tentang pil disebabkan kurangnya informasi dari petugas kesehatan salah satu mengerti tentang instruksi yang di berikan pada mereka.

Kadang-kadang hal ini disebabkan oleh kegagalan professional kesehatan dalam memberi informasi yang lengkap, penggunaan istilah-istilah medis, dan banyak memberikan instruksi yang harus diingat oleh penderita. Tak seorangpun mendapat mematuhi instruksi jika salah paham (tidak mengerti) tentang intruksi yang diberikan kepadanya.

Dari penelitian ini dapat dilihat kesimpulan bahwa perlu adanya sosialisasi yang banyak pada masyarakat tentang jenis-jenis dan metode kontrasepsi. Kehidupan masyarakat dapat dikendalikan apabila adanya program pelayanan KB yang dijalankan dari pemerintah.

\section{PENUTUP}

\section{Kesimpulan}

Berdasarkan hasil penelitian dan pembahasan dapat di simpulkan bahwa Tingkat pengetahuan tentang kontrasepsi oral pada Ibuibu di Puskesmas Jongaya Kecamatan Tamalate dalam kategori Baik dengan skor $(84,07 \%)$.

\section{Saran}

1. Pengetahuan ibu tentang pil KB perlu ditingkatkan khususnya para ibu yang belum memahami tentang penggunaan pil KB terkait penggunaan pasien lupa minum pil

2. Para pelayan kesehatan dan petugas kesehatan dapat memberikan pendidikan kesehatan (penyuluhan) tentang metode kontrasepsi pil dan cara penggunaan pil $\mathrm{KB}$ dengan baik dan benar.

\section{DAFTAR PUSTAKA}

Arum, Sujiatini. (2010) Panduan Lengkap Pelayanan KB terkini. Jogjakarta: Nuha Medika

Ayu, Ida. 2010. Ilmu Kebidanan, Penyakit Kandungan, Dan KB untuk Pendidikan bidan. Buku Kedokteran EGC: Jakarta

Handayani, Sri. 2010. Keluarga Berencana Dan Kontrasepsi. Cet 5. Yogyakarta: Pustaka Sinar Harapan.
Hartanto, Hanafi. 2006. Dan Keluarga Berencana Kontrasepsi. Cet.5. Jakarta: Pustaka Sinar Harapan.

Niven, H. 2002. Psikologi Kesehatan Pengantar untuk Perawat \& Profesional Kesehatan lain. Jakarta: EGC

Notoartmodjo, S. (2010). Metodologi Penelitian Kesehatan. Jakarta: Rineka Cipta.

Saifuddin, 2003. Buku PanduanPraktis Pelayanan Kontrasepsi. Jakarta: Yayasan Bina PustakaSarwono Prawirohardjo.

Saifuddin, Abdul Bari, et al. 2006. Buku Panduan Praktis Pelayanan Kontrasepsi. Jakarta: Yayasan Bina Pustaka Prawirohardjo.

Sulistyawati. 2011. Pelayanan Keluarga Berencana Cetakan 2. Jakarta: Salemba Medika.

Wiknjosastro, Hanifa. Et al. 2010. Ilmu Kandungan. Jakarta: Yayasan Bina Pustaka Sarwono Prawirohardjo.

Wulansari, pita dan Huriawati Hartono. 2006. Ragam Metode Kontrasepsi. Buku Kedokteran EGC: Jakarta 